\title{
Effect of Solar Heater Boxes and Constant Temperatures on Mortality and Developmental Stages of $\boldsymbol{C}$. maculatus
}

\author{
${ }^{1}$ Ragaa Mohammed Elbashier Elhadaa, ${ }^{2}$ Rita Muhamad Awang, \\ ${ }^{2}$ Dzolkhifli Omar, ${ }^{3}$ Uma Rani Sinniah and, ${ }^{4}$ Ionel Vaieriu Grozescu \\ ${ }^{I}$ Department of Plant Protection, Faculty of Agricultural Studies, Sudan University of Science and Technology \\ ${ }^{2}$ Department of Plant Protection, Faculty of Agriculture, University Putra Malaysia, 43400 UPM, Serdang \\ ${ }^{3}$ Department of Crop Science, Faculty of Agriculture, University Putra Malaysia, 43400 UPM, Serdang. \\ ${ }^{4}$ Faculty of Engineering, SEG: University College, Kota damansara
}

\begin{abstract}
Cardboard and Plywood were the materials which used for solar heater boxes to control adult and developmental stages of cowpea beetle Callosobruchus maculatus $(F$.) according to their effectiveness in previous study on solar heaters. The effect of solar heat on hatchability, oviposition, $4^{\text {th }}$ instars and mortality was evaluated. Adult mortality, hatchability, oviposition and adult emergence were significantly affected by solar heater boxes treatment. A temperature of $66.4^{\circ} \mathrm{C}$ was achieved in solar heater boxes within 15 minutes which caused $100 \%$ mortality of adults and $4^{\text {th }}$ larval instars of C. maculatus compared to $0 \%$ mortality after 1,2 and 3 days for untreated adults. Heat treatment decreased hatchability by $70 \%$ and $66.7 \%$ in Plywood and Cardboard respectively comparing with untreated eggs. To verify the effect of solar temperatures, another experiment was done using the oven. Adults of C. maculatus and eggs were exposed to constant temperatures to evaluate the effect on oviposition, adult emergence and mortality. Times needed for $100 \%$ adult's mortality were 10, 20, 40 and 50 minutes with temperatures of $70,60,50$ and $40^{\circ} \mathrm{C}$ respectively. The oviposition was also affected significantly by different temperatures.
\end{abstract}

Keywards: C. maculatus, solar heater boxes, constant temperatures

\section{Introduction}

In many regions, the losses of the quality and production of legume seeds are strict. Therefore it is necessary to develop technologies such as special storage facilities (Ishimoto et al., 1996). With the establishment of stored-product research and development at the beginning of $20^{\text {th }}$ century have come the many strategies for protection and disinfestation that we see today against the overabundance of insect pests that face up to the grain and food industry. The current status of stored product insect management in developed countries is in a period of transition from chemical methods to non-chemical methods, and hence there is great potential for using heat in stored products and associated structures. The use of heat to disinfest grain and structures considered as one feasible alternative to pesticides. It is comparatively rapid and does not leave any insecticide residues (Beckett et al., 2007). Different types of solar heaters using solar heating to disinfest grains, has bean found to control stored products insects effectively (Murdock and Shade, 1991; Ntoukam and Kich, 1992; Ntoukam et al, 1996; Bank, 1998; Nahdy et al 1998; Qaisrani and Bank, 2000; Chauhan and Ghaffar, 2002; Lale and Vidal, 2003; Mekasha et al 2006; Tilley et al., 2007). This experiment aims to determine the influence of heat treatment on developmental stages of cowpea weevil C. maculatus.

\section{1- Insect culture development}

\section{Material And Methods}

Seeds of adzuki bean which introduced from supermarket were sterilized through heat treatment at $70^{\circ} \mathrm{C}$ by putting in an oven for two hours. Stock culture of $C$. maculatus from about 5 pairs (plate5) was developed on the disinfested adzuki bean seeds (plate 6). The culture was maintained and allowed reproduce in the laboratory at room temperature in closed aquariums to avoid cross infestation. The aquarium was covered with muslin for aeration.

\section{2- Temperature recording}

Temperatures were sensed with "Type J" thermocouples fitted to "Intech Micro2100-A16" data logger. The temperature between seeds was detected using a $5 \mathrm{~mm}$ diameter thermocouple to sense the temperature that can affect the adults and eggs outside the seed. While temperature within seeds was measured using $1 \mathrm{~mm}$ diameter thermocouple inserted into the seed to sense the temperature which can affect the developmental stages. The $1 \mathrm{~mm}$ hole inside the seed was drilled with battery operated Standard PBC drill pit, $14.500 \mathrm{rpm}$. The 
hole around the thermocouples was sealed with instant filler to prevent air from entering seed cavity. $1 \mathrm{~mm}$ and $5 \mathrm{~mm}$ thermocouples were placed outside at about $15 \mathrm{~cm}$ above the ground to sense air temperature.

3. Effect of solar heat on developmental stages of $\boldsymbol{C}$. maculatus

\subsection{Effect of solar heat treatment on oviposition and adult mortality of $C$. maculatus}

Fifteen pairs of newly emerged adults for each treatment were introduced to one kilogram of clean adzuki bean seeds in Perspex tray in the middle of each solar heater box. The adults were exposed to heat treatment instantly after introduction. The exposure times for treatment were, 15, 30, 45, 60, 75, 90, and 120 minutes and untreated adults were included as a control. The experiment was done in completely randomize design with three replications. After each treatment the adults were separated from the seed by sieving through $3 \mathrm{~mm}$ mesh sieve to avoid eggs that could be oviposited instantly before or at some point in the early time of exposure when the generated heat could not influence the adults. The adults then introduced to about 100 clean seeds and kept in the laboratory under room temperature. Between-seed temperatures were measured as explained in section 2. Dead insects were counted within 1, 2 and 3 days after treatment and percent mortality was found. Eggs oviposited during the life period of the adults were counted to evaluate the influence of solar heat treatment on oviposition.

\subsection{Effect of solar heat treatment on egg hatchability of $C$. maculatus}

Newly emerged adults were positioned within disinfected seeds in aquarium and allowed to oviposit. The next day the adults were removed by sieving through $3 \mathrm{~mm}$ mesh sieve. For each treatment solar heater boxes containing one kilogram of adzuki bean seeds in a Perspex tray were interspaced with 30 eggs and subjected to heat instantly after removal of the adults. The eggs were exposed to heat for $15,30,45,60,75,90$, and 120 minutes and untreated eggs were included as a control. The experiment was done in completely randomize design with three replications. Between-seed temperature was recorded as explained in section 2 . The treated eggs then were kept in the laboratory under room temperature for six days. Hatched and unhatched eggs were noticed daily using binocular microscope. Hatching eggs were known by the movement of larva and the different in shell color according to present of proteins. The percent of egg hatchability was counted by dividing the proportion of hatched eggs to the total number of eggs multiply by 100.

\subsection{Effect of solar heat treatment on $4^{\text {th }}$ larval instar of $C$. maculatus}

Newly emerged adults were introduced to clean seeds of adzuki bean in aquarium and allowed to oviposit for one day. The next day the adults were sieved through $3 \mathrm{~mm}$ mesh sieve. Seeds with eggs were separated and kept in the laboratory under room temperature condition. According to Mekasha, 2004 the result of the study on the biology of developmental stages of the insect, time required for eggs to reach fourth instar from the first day of oviposition, was 18 days. Consequently, 30 seeds with eggs for each treatment were distributed within one kilogram of adzuki bean seeds and exposed to heat at this respective period to treat the fourth instar larva. The fourth instar larvae exposed to heat for 15, 30, 45, 60, 75, 90, and 120 minutes. Untreated check was included. The treated larvae from each treatment were kept in the laboratory under room temperature in Petri dishes. Number of emerged adults was noticed and percent of adult emergence was found in order to evaluate the effect of heat in the $4^{\text {th }}$ larval development. The experiment was done in completely randomize design in three replications. Within-seed temperatures were recorded as illustrated in section 2.

\section{Effect of constant heat on $C$. maculatus}

\subsection{Effect of constant heat on oviposition and adult mortality of $C$. maculatus}

To verify the effect of solar temperatures on the cowpea weevil C. maculatus, another experiment was done using the oven. Fifteen pairs of newly emerged adults for each treatment were introduced to 50 grams of clean adzuki bean seeds in Petri dish. The adults were exposed instantly after introduction to temperatures of 70 , 60,50 and $40^{\circ} \mathrm{C}$. The exposure times for treatments were, 10, 20, 30, 40, 50, 60, and 70 minutes and untreated adults were included as a control. After each treatment the adults were separated from the seed by sieving through 3 mesh sieve to avoid eggs that could be oviposited instantly before or at some point in the early time of exposure when the heat could not influence the adults. The adults then introduced to about 100 clean seeds and kept in the laboratory under room temperature. Dead insects were counted within 24, 48 and 72 hours after treatment and percent mortality was found. Eggs oviposited during the life period of the adults were counted to evaluate the influence of solar heat treatment on oviposition.

\subsection{Effect of constant heat on hatchability and adult emergence of $\mathrm{C}$. maculatus}

Newly emerged adults were positioned within disinfected seeds in aquarium and allowed to oviposit. The next day the adults were removed by sieving through $3 \mathrm{~mm}$ mesh sieve. For each treatment, $9 \mathrm{~cm}$ Petri dish containing 50grams of adzuki bean seeds were interspaced with 30 eggs and subjected to heat instantly after removal of the adults. The eggs were exposed to $40,50,60$, and $70^{\circ} \mathrm{C}$ for $10,15,30,40,50,60$, and 70 minutes 
and untreated eggs were included as control. The experiment was done in completely randomize design with three replications. The treated eggs next were kept in the laboratory under room temperature for six days. Hatched and unhatched eggs were noticed daily using binocular microscope. Hatching eggs were known by the movement of larva and the different in shell color according to present of proteins. The percent of egg hatchability was counted by dividing the proportion of hatched eggs to the total number of eggs multiply by 100 . Newly emerged adults were introduced to clean seeds of adzuki bean in aquarium and allowed to oviposit for one day. The next day the adults were sieved through $3 \mathrm{~mm}$ mesh sieve. Seeds with eggs were separated and exposed instantly to heat treatment at temperatures; $40,50,60$, and $70^{\circ} \mathrm{C}$ for $10,20,30,40,60$, and 70 minutes and untreated eggs were included as control check. The experiment was conducted in completely randomize design with three replications. The treated eggs then were kept in the laboratory under room temperature until the adults emerged. The percent of adult emergence were found.

\section{Data Analysis}

Percents of mortality, hatchability, and adult emergence data were root squire transformed while normal data was used for oviposition. Statistical Analysis Software (SAS) was used to analyze the data using analysis of variance (ANOVA) procedure and Duncan Multiple Range Test (DMRT) was used for mean comparison.

\section{Results And Discussion \\ 4.3.1 Effect of solar heat treatment on oviposition and adult mortality of C. maculatus}

Adult mortality was significantly affected by solar heat treatment (Figure 1). Exposure to heat for 15 minutes increased between-seed temperature in solar heater boxes to $66.4^{\circ} \mathrm{C}$ and $67.4^{\circ} \mathrm{C}$ for Cardboard and Plywood respectively which caused $100 \%$ mortality of adults. When the exposure time was extended to 30,45 , 60, 75, 90, and 120 minutes between-seed temperatures increased to $69.2,70.2,70.9,71.2,71.9,72.4^{\circ} \mathrm{C}$ respectively and certainly caused complete mortality for the adults. However, in untreated check none of the adults that were not exposed to heat treatment were killed. Solar heat treatment on adults was also affected the oviposition. All the adults of $C$. maculatus were died immediately without laying eggs for all exposure times. These results were in agreement with earlier findings. Fields (1992) mentioned that, the thermal death point for the cowpea weevil C. maculatus, is $57^{\circ} \mathrm{C}$. All the life stages of this insect were killed when exposed for one hour to this point (Murdock and Shade, 1991).

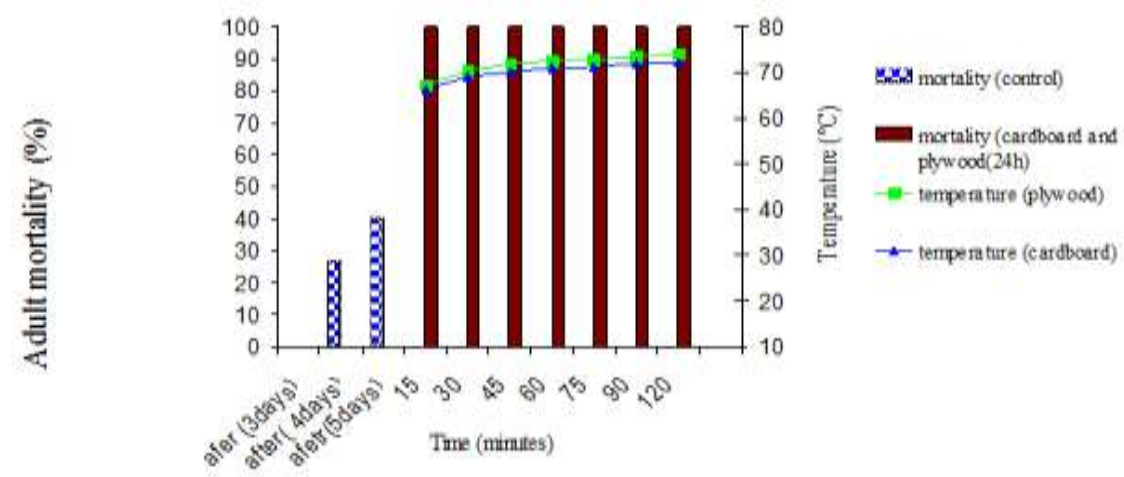

Figure 1. Effect of temperature of solar heater boxes on adult mortality of C. maculatus

A study done by Murdock and Shade (1991) on C. maculatus showed that, when the adults exposed to solar heat with temperature of $65^{\circ} \mathrm{C}$ complete mortality of all stages was achieved. Furthermore, according to Mekasha (2004) exposure to solar heat of adults of this insect in one kilogram of adzuki bean seeds for 45 minutes increased between seed-temperatures to $69.6^{\circ} \mathrm{C}$ and resulted in $100 \%$ mortality of the adult bruchids and restricted the oviposition. Maina and Lale (2004) investigated the effect of solar heat on C. maculatus, their results indicated significant effect on oviposition and adult progeny. Furthermore, study done by Lale and Ajayi (2001) resulted in complete adult mortality of C. maculatus when exposed to solar heat for 7, 14 and $24 \mathrm{~h}$.

\subsubsection{Effect of solar heat treatment on egg hatchability of C. maculatus}

Results of the effect of solar heat treatment on the hatchability of $C$. maculatus were represented in figure 2. Exposure of eggs to heat for 15 minutes increased the temperature between seeds to $66.4^{\circ} \mathrm{C}$ for Cardboard and $67.4^{\circ} \mathrm{C}$ for Plywood and decreased hatchability of eggs to $26.7 \%$ and $30 \%$ respectively which is significantly $(\rho \leq 0.05)$ lower from untreated eggs $(83.3 \%)$. Extended exposure time to 30 minutes and more, of heat treatment caused $100 \%$ mortality of egg. 
These results were nearly similar to some researcher findings. An experiment done by Mekasha (2004) indicated that, solar heat treatment of $C$. maculatus eggs reduced hatchability to $33.4 \%$ with temperature mean of $45.1^{\circ} \mathrm{C}$ for 15 minutes. However, extension of exposure times to heat for more than 30 minutes restricted egg hatchability. Moreover, Lale and Ajayi (2001) found that solarization for 7, 14 and 24 hours caused 100\% mortality of eggs for C. maculatus.

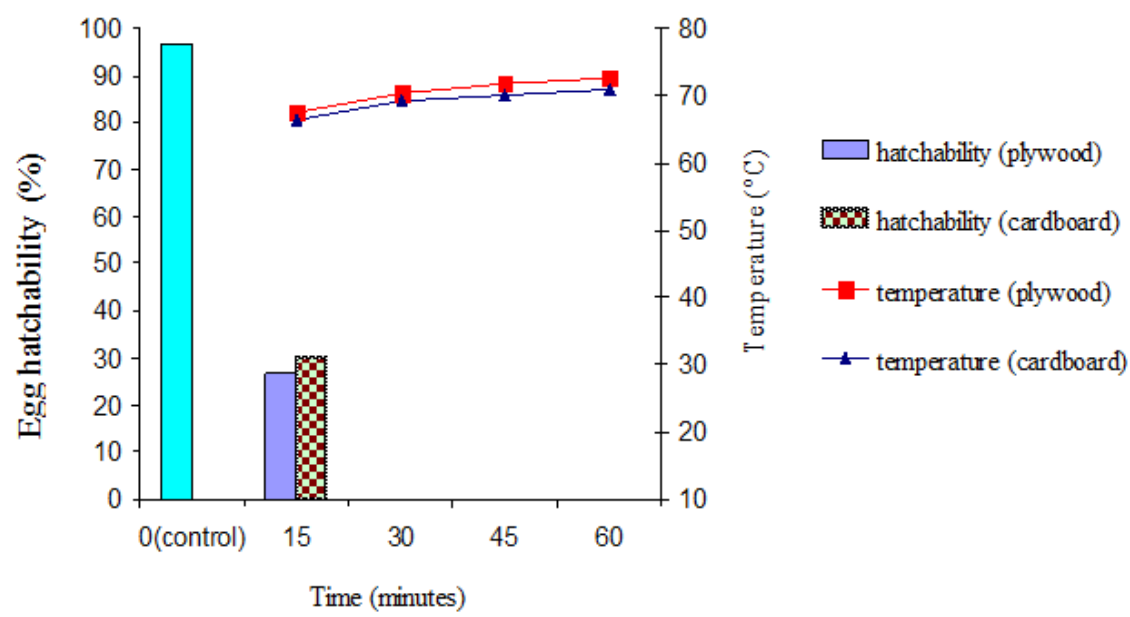

Figure 2. Effect of temperature of solar heater boxes on egg hatchability of C. maculatus

\subsubsection{Effect of solar heat treatment on $4^{\text {th }}$ larval instar of $C$. maculatus}

Solar heat treatment was observed to influence the fourth larval instar of the insect and adult emergence was significantly affected (Figure 3 ). Exposure of $4^{\text {th }}$ instars to heat for 15 minutes increased the temperature within seeds to $63.0^{\circ} \mathrm{C}$ for Plywood and $62.5^{\circ} \mathrm{C}$ for Cardboard solar heater boxes and decreased adult emergence to $23.3 \%$ and $26.6 \%$ respectively which is significantly $(\rho \leq 0.05)$ different when compared to adult emergence from untreated larvae $(82.2 \%)$. When the exposure times of heat treatment extended to 30 minutes and more the temperatures also increased and none of the treated larvae were able to reach adult stages.

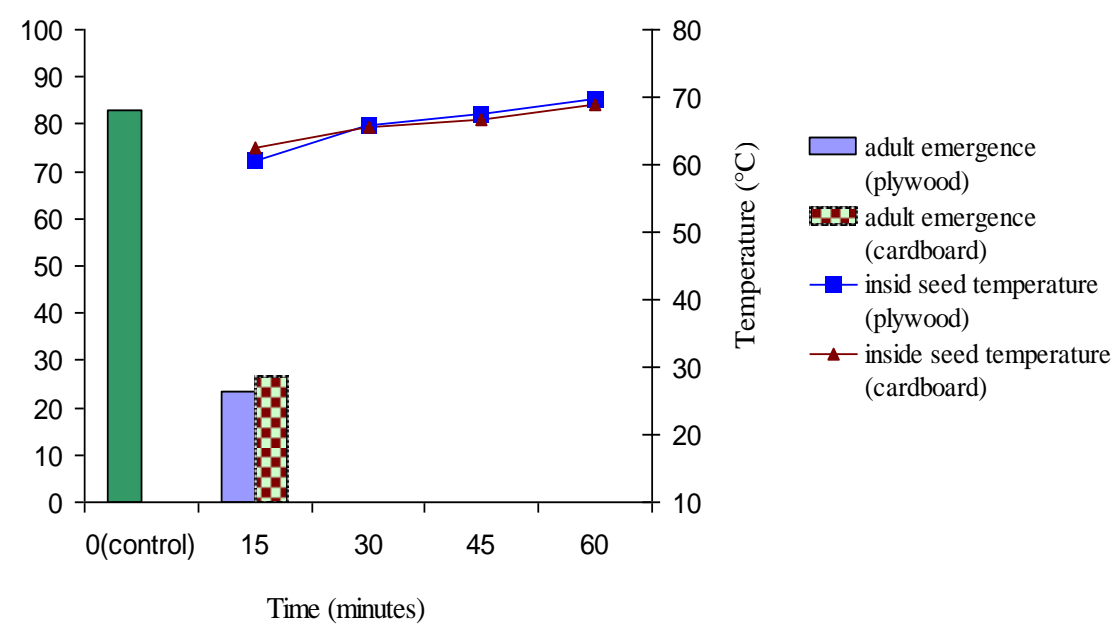

Figure 3. Effect of temperature of solar heater boxes on adult emergence of $C$. maculatus

Similar findings were reported by Mekasha (2004). When the larvae exposed to heat for 15 minutes, the temperatures within seed increased to $61.1^{\circ} \mathrm{C}$ and significantly reduced number of adult emergence and no adult emergence was noticed when exposure time extended to 30 minutes and more. Moreover, Murdock et al (1991) found that, exposed to solar heat at temperature of $57^{\circ} \mathrm{C}$ for one hour is sufficient to kill all developmental stages of $C$. maculatus. It seems that larvae stages need more time of exposure to cause complete mortality than that needs for adult mortality. In fact, larvae stages of this insect spend the whole life time inside the seeds. Lale, (1998) reported that, the seed cotyledons most likely protect developing larvae of C.maculatus against the solarization lethal effects. This may be why significantly higher percentages of adult emerged from larvae which exposed to the sun 15 minutes than from larvae exposed 30 minutes and more. 


\subsubsection{Effect of constant heat on developmental stages of $C$. maculatus}

Exposed to heat at $70^{\circ} \mathrm{C}$ strongly affected adult mortality and egg hatchability.Complete mortality was achieved instantly when adults exposed for just 10 minutes or less. Hatchability was $0.0 \%$ compared to $96.7 \%$ for untreated eggs. Exposed to heat at $60^{\circ} \mathrm{C}$ caused complete mortality instantly in 20 minutes of exposure while $100 \%$ mortality was achieved after one day in 10 minutes of exposure.No oviposition or hatchability was observed in these particular times (table 1).

Table 1. Effect of constant heat on mortality and developmental stages of C. maculatus

\begin{tabular}{|c|c|c|c|}
\hline \multirow[t]{2}{*}{$\begin{array}{l}\text { Exposure time } \\
\quad \text { (minutes) }\end{array}$} & \multicolumn{3}{|l|}{$\begin{array}{l}\text { Temperatures } \\
60^{\circ} \mathrm{C}\end{array}$} \\
\hline & Mortality (\%) & Hatchability (\%) & Oviposition (\%) \\
\hline $\mathrm{CK}^{\mathrm{a}}$ & 0.0 & 96.7 & 82.3 \\
\hline 10 & $100(24 \mathrm{~h})$ & 0.0 & 0.0 \\
\hline 20 & 100 & 0.0 & - \\
\hline
\end{tabular}

$\mathrm{CK}^{\mathrm{a}} \quad$ Untreated control

Table 2 and 3 showed the effect of the constant temperature on oviposition, hatchability, adult mortality and adult emergence of $C$. maculatus when exposed to $50^{\circ} \mathrm{C}$ and $40^{\circ} \mathrm{C}$ for different exposure times. The results indicated that, oviposition and egg hatchability were significantly affected by these points of temperature when compared to untreated check. Oviposition and hatchability percent decreased when exposure time increased.

Table 2. Effect of constant heat on developmental stages and mortality of C. maculatus

\begin{tabular}{|c|c|c|c|c|c|c|}
\hline \multirow{3}{*}{$\begin{array}{c}\text { Exposure time } \\
\text { (minutes) }\end{array}$} & \multicolumn{6}{|c|}{ Temperatures $\left(50^{\circ} \mathrm{C}\right)$} \\
\hline & \multirow[t]{2}{*}{$\begin{array}{c}\text { \# Oviposition } \\
\text { (Eggs) }\end{array}$} & \multirow[t]{2}{*}{$\begin{array}{c}\text { Hatchability } \\
(\%)\end{array}$} & \multicolumn{3}{|c|}{$\begin{array}{c}\text { Adult mortality } \\
(\%)\end{array}$} & \multirow{2}{*}{$\begin{array}{c}\text { Adult } \\
\text { emergence } \\
(\%)\end{array}$} \\
\hline & & & $24 \mathrm{~h}$ & $48 \mathrm{~h}$ & $72 \mathrm{~h}$ & \\
\hline $\mathrm{CK}^{2}$ & $82.3^{2}$ & $96.7^{a}$ & $0.0^{\mathrm{b}}$ & $0.0^{c}$ & $0.0^{c}$ & $82.2^{2}$ \\
\hline 10 & $33.0^{b}$ & $90.0^{a b b}$ & $3.3^{\mathrm{ab}}$ & $10.0^{\mathrm{bc}}$ & $20.0^{b}$ & $50.0^{b}$ \\
\hline 20 & $21.3^{c}$ & $73.3^{\mathrm{be}}$ & $6.7^{\mathrm{ab}}$ & $10.0^{\mathrm{be}}$ & $30.0^{b}$ & $46.7^{b}$ \\
\hline 30 & $9.5^{d}$ & $60.0^{c}$ & $6.7^{a b}$ & $20.0^{a b}$ & $53.3^{a}$ & $30.0^{c b}$ \\
\hline 40 & $0.0^{\circ}$ & $36.7^{\mathrm{d}}$ & $10.0^{4}$ & $30.0^{s}$ & $60.0^{3}$ & $13.3^{\mathrm{e}}$ \\
\hline C.V\% & 16.5 & 13.5 & 50.6 & 47.7 & 16.3 & 28.9 \\
\hline
\end{tabular}

$\mathrm{CK}^{\mathrm{a}} \quad$ Untreated control

*1 No of eggs/female, during life.

$*^{2} \quad$ from treated 4 th instars

For each set of comparison means followed by the same letters are not significantly different $(\rho \geq 0.05)$

Adult mortality significantly affected by heat treatments at 48 hours for both points of temperatures. From tables 2 and 3 it was clear that, heat treatment was also affected

adult emergence from treated fourth instars when they exposed to heat at $40^{\circ} \mathrm{C}$ and $50^{\circ} \mathrm{C}$ for different exposure times.

Haines (1991) mentioned that the suitable temperature for most favorable oviposition and development of $C$. maculatus is $30-35^{\circ} \mathrm{C}$. Study done by Lale and Vidal (2003b) indicated that difference in temperature could have huge effect on oviposition and

development of $C$. maculatus. Oviposition was decreased significantly at temperature of $40^{\circ} \mathrm{C}$ and the eggs failed to develop into adults.

Table 3. Effect of constant heat on developmental stages and mortality of C. maculatus

\begin{tabular}{|c|c|c|c|c|c|c|}
\hline \multirow{3}{*}{$\begin{array}{c}\text { Exposure time } \\
\text { (minutes) }\end{array}$} & \multicolumn{6}{|c|}{ Temperatures $\left(40^{\circ} \mathrm{C}\right)$} \\
\hline & \multirow[t]{2}{*}{$\begin{array}{c}{ }^{* 1} \text { Oviposition } \\
\text { (Eggs) }\end{array}$} & \multirow[t]{2}{*}{$\begin{array}{c}\text { Hatchability } \\
(\%)\end{array}$} & \multicolumn{3}{|c|}{$\begin{array}{c}\text { Adult mortality } \\
(\%)\end{array}$} & \multirow{2}{*}{$\begin{array}{l}*^{* 2} \text { Adult } \\
\text { emergence } \\
(\%)\end{array}$} \\
\hline & & & $24 \mathrm{~h}$ & $48 \mathrm{~h}$ & $72 \mathrm{~h}$ & \\
\hline $\mathrm{CK}^{\mathrm{a}}$ & $82.3^{\mathrm{a}}$ & $96.7^{\mathrm{a}}$ & $0.0^{b}$ & $0.0^{\mathrm{d}}$ & $0.0^{\mathrm{d}}$ & $82.2^{\mathrm{a}}$ \\
\hline 10 & $48.2^{b}$ & $96.7^{\mathrm{a}}$ & $0.0^{b}$ & $3.3^{\mathrm{d}}$ & $10.0^{\mathrm{d} c}$ & $70.0^{\mathrm{ab}}$ \\
\hline 20 & $36.1^{c}$ & $90.0^{\mathrm{ab}}$ & $0.0^{b}$ & $6.7^{\mathrm{d} c}$ & $13.3^{\mathrm{dc}}$ & $66.7^{a b}$ \\
\hline 30 & $27.4^{d}$ & $90.0^{\mathrm{ab}}$ & $0.0^{b}$ & $16.7^{\mathrm{bc}}$ & $23.33^{b c}$ & $66.7^{\mathrm{ab}}$ \\
\hline 40 & $14.1^{\mathrm{e}}$ & $70.0^{\mathrm{bc}}$ & $0.0^{b}$ & $20.0^{\mathrm{ab}}$ & $30.0^{\mathrm{abc}}$ & $53.3^{\mathrm{ab}}$ \\
\hline 50 & $9.4^{\text {ef }}$ & $60.0^{c}$ & $3.3^{\mathrm{ab}}$ & $30.0^{\mathrm{a}}$ & $36.7^{\mathrm{ab}}$ & $50.0^{\mathrm{ab}}$ \\
\hline 60 & $4.7^{f}$ & $53.3^{c}$ & $10^{\mathrm{a}}$ & $30.0^{\mathrm{a}}$ & $46.7^{\mathrm{a}}$ & $33.3^{b}$ \\
\hline C.V\% & 11.8 & 14.3 & 87.0 & 30.5 & 29.1 & 34.2 \\
\hline
\end{tabular}


$\mathrm{CK}^{\mathrm{a}}$ Untreated control

*1 No of eggs/female, during life.

$*^{2} \quad$ from treated 4 th instars

For each set of comparison means followed by the same letters are not significantly different $(\rho \geq 0.05)$

Lale (1998) mentioned that, a previous study was done by Iloba and Osuji (1986). They found that adults of $C$. maculatus when exposed to temperatures higher than $40^{\circ} \mathrm{C}$ survived up to 4 hours at $47.5^{\circ} \mathrm{C}$ but death occurred at $51.3^{\circ} \mathrm{C}$ in 15 minutes. Furthermore, an experiment in an oven conducted by Murdock et al (1991) resulted in complete mortality of larvae, pupae and adults of $C$. maculatus when exposed to heat of up to $57.3^{\circ} \mathrm{C}$ for one hour.The mortality of an insect stage at high temperatures is a function of temperature and exposure time. At any given temperature, mortality increases with an increase in exposure time. In temperature above $55^{\circ} \mathrm{C}$, there is rapid mortality where the insect is dead in minutes or seconds (Beckett et al., 2007). High temperatures are known to lower egg production and to stop the ability of movement and finally caused death in adult insects (Lale, 1998). Death of bruchids at high temperatures may result from various factors. Their limited physiological ability to thermoregulate, denatured of proteins, nucleic acids, lipids and carbohydrates or the interruption of the balance of metabolic process which build up toxic production (Murdock et al., 1997; Lale, 1998; Beckett et al., 2007). In this study, the decline of oviposition as well as the mortality of eggs, adults, and $4^{\text {th }}$ instars' larvae might have been due to a combination of the adverse effect of high temperatures.

\section{Conclusion}

Adult mortality, hatchability, oviposition and adult emergence were significantly affected by solar heater boxes treatment. Complete mortality was achieved when adults exposed to heat for 15 minutes at $66.4^{\circ} \mathrm{C}$ compared to $0 \%$ mortality after 24, 48 and 72 hours for untreated adults. Times needed for $100 \%$ adult's mortality were $10,20,50$ and 70 minutes with temperatures of $70,60,50$ and $40^{\circ} \mathrm{C}$ respectively.

\section{Acknowledgment}

Many thankful to the University Putra Malaysia (UPM) for sponsoring the research through the Faculty of Agriculture, Department of Plant Protection.

\section{References}

[1]. Banks, H.J., (1998). Prospects for Heat Disinfestation .Stored grain Research laboratory, CSIRO Entomology, Canberra.

[2]. Beckett, S.J, Fields, P.G, and Subramanyam, BH., (2007). Disinfestation of stored products and associated structures using heat. In Tang, E. M. J., Wang, S. and Lurie, S. (Ed.), Heat treatment for postharvest pest control. Reading: CABI.

[3]. Chauhan, Y. S., and Ghaffar, M. A., (2002). Solar heating of seeds-a low cost method to control bruchid (Callosobruchus spp.) attack during storage of pigeonpea. Journal of Stored Products Research, 38(1), 87-91.

[4]. Ishimoto,M.,Sato,T., Crispeels,M.J.,and Kitamura,K.(1996).Bruchid resistance of transgenic azuki bean expressing seed-amylase inhibitor of common bean. Entomologia experimentalis et applicata,79(3),309-315.

[5]. Lale, N. E. S., Vidal, S. (2003). Simulation studies on the effects of solar heat on egg- laying, development and survival of Callosobruchus maculatus (F.) and Callosobruchus subinnotatus (Pic) in stored bambara groundnut Vigna subterranean (L.) Verdcourt. Journal of Stored Products Research, 39(5), 447-458.

Mekasha, C., Dzolkifli, O., Yusuf, S., Rita, M., and Noorma, O., (2006). Effect of heat treatment on developmental stages of Callosobruchus maculatus (Coleoptera: Bruchidae) in stored adzuki bean Vigna angularis .International Journal of Tropical Insect Science, 26(4), 273-279.

[6]. Murdock, L. L., and Shade, R. E., (1991). Eradication of cowpea weevil (Coleoptera: Bruchidae) in cowpeas by solar heating. American Entomologist, 37(4), 228- 231.

[7]. Nahdy,M.S. and Agona,J.A.1998. Effect of Solar Drying Period of Beans on Seed Viability, Time Injuriousness of Acanthoscelides obtectus Say.

[8]. Ntoukam, G., and Kitch, L. W. (1992). Solar heaters for improved cowpea storage: Agronomic Research Institute of Cameroon, Maroua Research Center, CRSP Powpea Storage Project.10- Ntoukam, G., Kitch, L. W., Shade, R. E., and Murdock, L. L. (1997). A novel method for conserving cowpea germplasm and breeding stocks using solar disinfestation. Journal of Stored Products Research, 33(2), 175-179.

[9]. Qaisrani, R., and Banks, J. (2000). The prospects for heat disinfestation of grain. Paper presented at the Australian Postharvest Technical Conference.

[10]. Tilley, D. R., Casada, M. E., andArthur, F. H. (2007). Heat treatment for disinfestations of empty grain storage bins. Journal of Stored Products Research, 43(3), 221-228. 